Research Paper

\title{
No Evidence for Lower Levels of Serum Vitamin D in the Presence of Hepatic Steatosis. A Study on the Portuguese General Population
}

Jorge Leitão ${ }^{\bowtie}$, Sofia Carvalhana², Ana Paula Silva ${ }^{3}$, Francisco Velasco ${ }^{4}$, Isabel Medeiros ${ }^{5}$, Ana Catarina Alves 6 , Mafalda Bourbon', Bárbara Oliveiros7, Armando Carvalho ${ }^{1}$, Helena Cortez-Pinto ${ }^{8}$

1. Internal Medicine, Centro Hospitalar e Universitário de Coimbra EPE, Praceta Prof. Mota Pinto 3000-075 Coimbra, Portugal, Faculty of Medicine, University of Coimbra, Portugal, Azinhaga de Santa Comba, Celas 3000-548 Coimbra, Portugal;

2. Serviço de Gastroenterologia, Hospital de Santa Maria, Laboratório de Nutrição, FML, Universidade de Lisboa, Av. Prof. Egas Moniz, 1649-035 Lisboa, Portugal.

3. Serviço de Gastroenterologia, Centro Hospitalar de Vila Nova de Gaia e Espinho, EPE, Rua Conceição Fernandes, 4434-502 Vila Nova de Gaia.

4. Serviço de Gastrenterologia, Centro Hospitalar Universitário do, Algarve, EPE- Hospital de Faro, Leão Penedo, 8000-386 Faro, Portugal.

5. Serviço de Gastroenterologia, Hospital Espírito Santo E.P.E, Évora, Largo Senhor da Pobreza, 7000-811 Évora, Portugal.

6. Biosystems and Integrative Science Institute (BioISI), Instituto Nacional de Saúde Dr. Ricardo Jorge, Avenida Padre Cruz, 1649-016 Lisboa, Portugal

7. Laboratório de Bioestatística e Informática Médica, Faculdade de Medicina, Universidade de Coimbra, Azinhaga de Santa Comba, Celas 3000-548 Coimbra, Portugal.

8. Serviço de Gastroenterologia, Hospital de Santa Maria, Laboratório de Nutrição, Faculdade de Medicina, Universidade de Lisboa, Portugal, Av. Prof. Egas Moniz, 1649-035 Lisboa, Portugal.

$\triangle$ Corresponding author: Jorge Leitão, Internal Medicine A, Centro Hospitalar e Universitário de Coimbra. Praceta Carlos da Mota Pinto 3000-075 Coimbra. Tel: +351 239400400. Fax: (+351239401045). E-mail address: 7820@chuc.min-saude.pt

(c) Ivyspring International Publisher. This is an open access article distributed under the terms of the Creative Commons Attribution (CC BY-NC) license (https://creativecommons.org/licenses/by-nc/4.0/). See http://ivyspring.com/terms for full terms and conditions.

Received: 2018.04.09; Accepted: 2018.09.22; Published: 2018.11.29

\begin{abstract}
Introduction and aims: Nonalcoholic fatty liver disease (NAFLD) has become highly prevalent, paralleling the pandemic of obesity and diabetes, and represents an important burden. Nutrition knowledge is fundamental, in prevention, evolution and treatment of NAFLD. Association of low serum levels of vitamin D (VD) with several diseases, including NAFLD, has been emphasized in the last decade.

We evaluated how serum levels of VD correlate with the presence of hepatic steatosis, and VD intake, in a random sample of the Portuguese adult population.

Methods: Participants underwent a dietary intake inquiry, using a semi-quantitative food frequency questionnaire representative of the usual intake over the previous year. Anthropometric measures, blood tests and ultrasound were done. Hepatic steatosis was quantified according to Hamaguchi's ultrasonographic score (steatosis defined by a score $\geq 2$ ).

Results: We recruited 789 adult individuals, 416 males (52.7\%), mean age of $49.9 \pm 17.0$ years (18-79). Prevalence of hepatic steatosis was $35.5 \%$, and after exclusion of excessive alcohol consumption, $28.0 \%$. Mean VD serum levels were $26.0 \pm 9.8 \mathrm{ng} / \mathrm{ml}$ and $68.4 \%$ participants had serum VD levels below $30 \mathrm{ng} / \mathrm{ml}$. Mean serum levels of VD were not significantly different between participants with steatosis vs. no steatosis: $25.2 \pm 8.7$ vs. $26.4 \pm 10.3 \mathrm{ng} / \mathrm{ml}$, respectively $(p=0.071)$. There was no correlation between VD serum levels and VD intake, measured by the FFQ, $r=0.075(p=0.383)$.

Conclusions: In spite of a high prevalence rate, there was no evidence that decreased VD serum levels were associated with hepatic steatosis. No significant correlation was found between VD dietary ingestion and VD serum levels.
\end{abstract}

Key words: Hepatic steatosis; nonalcoholic fatty liver disease; vitamin D; common population

\section{Introduction}

Nonalcoholic fatty liver disease (NAFLD) abnormal liver tests and chronic hepatic disease, emerged in the last decades as a leading cause of paralleling the rising prevalence of diabetes, obesity, 
metabolic syndrome (MS), over-nutrition and sedentary lifestyle, all of which known as risk factors for NAFLD. Although with great differences worldwide, between $25 \%$ and $45 \%$ of the general population, at least in some western countries and in selected populations [1-3], have NAFLD. In some of them, by circumstances still not completely understood, the disease will progress with hepatic inflammation, ballooning and fibrosis, composing nonalcoholic steatohepatitis (NASH), a known condition characterized by an important risk for cirrhosis, hepatocellular carcinoma, and/or liver failure. These two facts together concur to the possibility that NAFLD may become the major etiology of chronic liver disease and need for liver transplantation, in a near future. In spite of achievements in the understanding of the disease, there are, however, several unresolved issues, whose enlightening is fundamental for diagnosis and treatment.

Vitamin D (VD) is a secosteroid hormone mainly synthesized in skin by action of ultraviolet B sunlight radiation in 7-dehydrocholesterol (Vitamin D3), and in a lesser percentage obtained from diet, especially oily fish and egg yolk (vitamin D2) [4]. The hormonal active form, 1,25-dihydroxyvitamin $\mathrm{D},\left[1,25(\mathrm{OH})_{2} \mathrm{D}_{3}\right]$, is obtained after two hydroxylations, of both vitamin D2 and vitamin $\mathrm{D} 3$, in liver $\left[25(\mathrm{OH}) \mathrm{D}_{3}\right]$ and kidney [5]. Since $\left[25(\mathrm{OH}) \mathrm{D}_{3}\right]$ has a long half-life and rather stable serum levels, it is usually the form measured in blood samples [6]. VD cellular effects are mediated by a nuclear receptor (VDR), member of nuclear hormonal receptor present in a large variety of different cells and organs, and not only in the bone tissue $[6,7]$.

Although VD only has an established role in bone health, there has been an enormous interest in the potential non-skeletal benefits of VD. Many recently published studies evidenced pleiotropic effects of VD, for instance in innate and adaptive immune system [8-10], or in cellular differentiation and proliferation, with possible participations in epidermal proliferation, apoptosis and DNA repair $[11,12]$. It was also shown an inverse relation between VD levels and presence of diabetes [13, 14], with a possible interaction with $\beta$ cells $[15,16]$, as well as a positive correlation between VD levels and adiponectin [17-20]. Animal studies demonstrated that hypovitaminosis D decreases islet beta cell function and insulin sensitivity, contributing to loss of glycaemic control, and suggests that VD modulates hepatic, glucose and lipid metabolism and promotes pancreatic islet function and survival [21, 22], attributing to $\mathrm{VD}$, a role in prevention and management of obesity-induced type 2 diabetes mellitus and NAFLD.

Furthermore, several observational studies associated low levels of VD with insulin resistance (IR), the MS [23], and cardiovascular diseases [24, 25]. Similarly, NAFLD/NASH patients had lower levels of VD than controls in two meta-analysis [26, 27]. Furthermore, one study reported that among patients with NAFLD, low VD is associated with worse liver histology [28]. VD was also shown to have a repressive effect on type I collagen formation in human stellate cells, with a potential effect on hepatic fibrosis regression [29]. However, other studies did not corroborate the suggested association between low serum levels of VD and NAFLD [30-32]. In one of these studies, neither the presence of insufficiency (20-30 ng/ml) nor deficiency $(<20 \mathrm{ng} / \mathrm{ml}$ ) was associated with more severe liver histology on liver biopsy [30]. Despite some benefit of VD supplementation in patients with IR [14], as well as in rats with diet induced steatohepatitis [33], no benefit was found in individuals with normal glucose tolerance [34].

In spite of some epidemiological and experimental evidence of association between VD deficiency and NAFLD, the true relevance of hypovitaminosis D in NAFLD, and the real direction of a possible association between them, is still a matter of debate that needs to be clarified. Until now, no data was available from the population of Portugal, a southern European and sunny country.

The main goal of the present study was to evaluate how the serum levels of VD vary with the presence of hepatic steatosis and how they are associated with VD intake, using a large sample of the general Portuguese population.

\section{Methods}

\section{Study cohort}

We carried out a nationwide voluntary population-based cross-sectional study, using a random cluster sampling. The study population included Portuguese adults resident in the mainland (18-79 years old). The selection of the population for this study was performed on the basis of a random selection of two ACES [Agrupamentos de Centros de Saúde (Groups of Primary Care Settings)], out of five Nomenclature of Territorial Units for Statistics II regions, of mainland Portugal (Northern, Central, Lisbon and Tagus Valley, Alentejo, and Algarve). Within each ACES a second random selection of four primary care settings was performed.

The study was approved by the national commission for protection of citizens personal data ("Comissão Nacional de Protecção de Dados"). 
This study was conducted according to the guidelines laid down in the Declaration of Helsinki and all procedures involving human subjects were approved by the Ethical Committee of Coimbra Medical School (CE-15/2012). Written informed consent was obtained from all subjects.

\section{Study collection}

The study was carried out between 2012 and 2015, in different seasons of the year (spring/summer and autumn/winter). After selection, individuals were invited by letter to participate in the study, which was designed to assess the prevalence of cardiovascular risk factors in the Portuguese population. Participation was about 35\%, corresponding to 1685 participants. The study participants were then invited to participate in a sub-study on the prevalence of hepatic steatosis (HS) and viral hepatitis.

After written informed consent was obtained, blood samples were collected and a questionnaire was used to characterize socio-demographic data (sex, age, district of residence, birthplace, race), anthropometric variables (weight, height, and waist circumference), living habits of alcohol consumption, smoking, and level of physical activity.

The participants were evaluated after a 12-hour fast. Data was collected including biographic data, past medical history, medication, smoking and exercise habits (applying the "International Physical Activity Questionnaire: 12-Country Reliability and Validity") [35], complete physical examination with abdominal circumference, and Body Mass Index (BMI).

Complete biochemical tests were evaluated in all participants, including serum insulin and VD levels (Electro-chemiluminescence binding assay-ECLIA). VD serum levels, were adopted from the Endocrine Society Practice Guideline, that defines VD insufficiency as 25-(OH)D serum levels between 21 and $29 \mathrm{ng} / \mathrm{mL}$, and deficiency serum levels less than $20 \mathrm{ng} / \mathrm{mL}$ [36]. Insulin resistance, was calculated by HOMA-IR test [37], and the presence of MS was calculated using the criteria proposed by the American Heart Association/National Heart, Lung, and Blood Institute Scientific Statement (AHA/NHLBI) criteria [38].

Diabetes was assumed in the participants with past medical history of treated diabetes, or, with a confirmed fasting glycaemia above $126 \mathrm{mg} / \mathrm{dl}$ (WHO. Definition and diagnosis of diabetes mellitus and intermediate hyperglycemia. At, http://www. who.int/diabetes/publications/Definition and diagnosis of diabetes_new.pdf) and a glycated hemoglobin level of $6.5 \%$ or superior (WHO. Use of
Glycated Haemoglobin (HbA1c) in the Diagnosis of Diabetes Mellitus. At http://www.who.int/diabetes/ publications/report-hba1c_2011.pdf).

The assessment of the dietary intake was done with a semi-quantitative food frequency questionnaire (FFQ), validated for the Portuguese population [39], and applied by an experienced nutritionist, with help from of a photographic manual as a visual support to allow the choice of multiples and sub-multiples of each portion, representative of the usual intake over the previous year. For detailed nutrient analysis, the Food Processor Plus Program version 5.0 (ESHA Research, Salem, OR, USA) was used, based on values from the US Department of Agriculture. In addition, values for typical Portuguese foods were computed using the Portuguese tables of food composition. Average alcoholic consumption and evidence of harmful drinking and dependence was assessed with the AUDIT (Alcohol Use Disorders Identification Test) questionnaire. Excessive alcohol intake was defined as daily alcohol consumption more than $20 \mathrm{~g}$ for women, and more than $30 \mathrm{~g}$, for men. For statistical analysis purpose, participants were distributed in three different groups: absence of alcohol consumption, moderate drinkers (less than $20 \mathrm{~g} /$ day in women and 30/day in men), and excessive drinkers (above those limits) [40, 41].

To diagnose HS, an imagiological method was elected, as all participants were evaluated in tertiary centers, with availability of US and experienced operators. HS was quantified according to Hamaguchi's ultrasonography score (0-6) with presence of steatosis defined by a score $\geq 2$ [42], using a SIEMENS S 2000 with a $4 \mathrm{MHz}$ probe. All operators, rigidly following Hamaguchi's criteria, did imaging evaluation and the results were confirmed by a staff radiologist.

\section{Statistics}

Multiple linear regression was used to determine the predictor factors of serum VD. The method was validated by a Durbin-Watson statistic $=1.94$, with no collinearity between the independent variables, since VIF (Variance Inflaction Factor) was 1.92. Comparisons using hepatic steatosis as an independent factor were performed by a Student's $t$ test, considering the sample size and that dependents were not assimetrically distributed. Pearson's correlation coefficient was used to access correlation between serum VD and its intake.

Statistical analysis was performed using SPSS 23.0, with a significance level of 0.05 .

\section{Results}

We enrolled 789 participants, 416 males (52.7\%), 
with a mean age of $49.9 \pm 17.0$ years (from 18 to 79 years old). Characteristics of the studied cohort are summarized in Table 1 . The majority of participants were Caucasians (97.8\%).

HS was present in $35.5 \%$ of the participants, and excluding those with harmful alcohol consumption $(>20 \mathrm{~g} /$ day in females and $>30 \mathrm{~g} /$ day in males), the prevalence was $28 \%$. HS was more prevalent in men $(44.7 \%)$, than in woman $(25.2 \%)$, and was associated with older age (55.9 vs. 46.6 years, respectively, $\mathrm{p}<0.001)$.

Table 1. Characteristics of the study population $(n=789)$

Age (vears)

Gender: male (\%)

BMI $(\mathrm{Kg} / \mathrm{m} 2)$

Waist circumference $(\mathrm{cm})$

Race (Caucasians; \%)

Systolic BP (mm Hg)

Diastolic BP (mm Hg)

Hepatic steatosis (all participants)

Hepatic steatosis (without excessive alcohol

Serum vitamin $\mathrm{D}(\mathrm{ng} / \mathrm{ml})$ :

Mean \pm SD (range)

$<20 \mathrm{ng} / \mathrm{ml}(\mathrm{n}, \%)$

21-29 ng/ml (n, \%)

$>30 \mathrm{ng} / \mathrm{ml}(\mathrm{n}, \%)$

Total cholesterol (mg/dl)

Triglycerides $(\mathrm{mg} / \mathrm{dl})$

HDL (mg/dl)

LDL (mg/dl)

Glycaemia $(\mathrm{mg} / \mathrm{dl})$

Insulin Resistance, HOMA Test > 2.5 (n, \%)

Metabolic syndrome $\mathrm{n}(\%)$

Diabetes mellitus n (\%)

Glomerular Filtration Rate (GFR)

$>90 \mathrm{ml} /$ minute $(\mathrm{n}, \%)$

$60-90 \mathrm{ml} /$ minute $(\mathrm{n}, \%)$

$<60 \mathrm{ml} /$ minute (n, \%)

Smokers (n, \%) (proportion who ever smoked) $49.9 \pm 17.0(18-79)$

$416(52.7 \%)$

$27.0 \pm 4.8$

$93.0 \pm 12.9$

$772(97.8 \%)$

$127.9 \pm 21.35$

$80.3 \pm 11.2$

$280(35.5 \%)$

$139(28.0 \%)$

$25.9 \pm 9.8(4.9-70.0)$

$227(28.8 \%)$

$313(39.7 \%)$

$249(31.6 \%)$

$197.38 \pm 37.57$

$111.1 \pm 76.4$

$56.2 \pm 15.4$

$122.36 \pm 34.67$

$94.93 \pm 22.53$

$268(34.0 \%)$

$156(19.8 \%)$

$71(8.9 \%)$

$589(74.7 \%)$

$182(23.1 \%)$

$18(2.3 \%)$

$128(16.2 \%)$

Legend: * Females: $<20 \mathrm{~g} /$ day; Males: $<30 \mathrm{~g} /$ day. Vitamin D: deficiency $(<20$ $\mathrm{ng} / \mathrm{ml})$, insufficiency $(21-29 \mathrm{ng} / \mathrm{ml})$, recommended $(>30 \mathrm{ng} / \mathrm{ml}$ )

As shown in table 2, presence of steatosis was associated mainly with the features of the MS and excessive alcohol ingestion.

There were also no significant differences in serum VD levels between males and females: $26.2 \pm$ $9.4 \mathrm{ng} / \mathrm{ml}$ and $25.7 \pm 10.2 \mathrm{ng} / \mathrm{ml}$, respectively. Only $31.6 \%$ participants had serum VD above $30 \mathrm{ng} / \mathrm{ml}$. Furthermore, there were no differences between mean VD serum levels of the participants evaluated in spring/summer and those who were evaluated in autumn/winter $(\mathrm{p}=0.785)$.

Mean serum VD levels were $26.0 \pm 9.8 \mathrm{ng} / \mathrm{ml}$ (min: 5.0; max: 70.0). Mean serum levels of VD were not statistically different in participants with steatosis vs. no steatosis: $25.2 \pm 8.7$ vs. $26.4 \pm 10.3 \mathrm{ng} / \mathrm{ml}$, respectively $(p=0.071)$ (Figure 1$)$. In participants with serum VD levels below $20 \mathrm{ng} / \mathrm{ml}$, the prevalence of HS was $36.6 \%$, in those with serum VD $21-29 \mathrm{ng} / \mathrm{ml}$ was $39 \%$, and in those with serum VD above $30 \mathrm{ng} / \mathrm{ml}$ was $30.1 \%$. There was a non-significant trend for less HS in participants with serum VD above $30 \mathrm{ng} / \mathrm{ml}$ $(p=0.086)$.

Table 2. Comparison of metabolic parameters with presence or absence of hepatic steatosis

\begin{tabular}{|c|c|c|c|c|c|}
\hline & Steatosis & $\mathrm{n}$ & Mean & SD & $\mathrm{p}$ \\
\hline \multirow[t]{2}{*}{ Age } & No & 509 & 46.5 & 17.4 & \multirow[t]{2}{*}{$<0.001$} \\
\hline & Yes & 280 & 55.9 & 14.4 & \\
\hline \multirow[t]{2}{*}{ Vitamin D (ng/ml) } & No & 509 & 26.4 & 10.3 & \multirow[t]{2}{*}{0.071} \\
\hline & Yes & 280 & 25.1 & 8.7 & \\
\hline \multirow[t]{2}{*}{ BMI $\left(\mathrm{kg} / \mathrm{m}^{2}\right)$} & No & 509 & 25.5 & 3.9 & \multirow[t]{2}{*}{$<0.001$} \\
\hline & Yes & 280 & 29.7 & 4.8 & \\
\hline \multirow[t]{2}{*}{ Waist (cm) } & No & 508 & 88.5 & 11.3 & \multirow[t]{2}{*}{$<0.001$} \\
\hline & Yes & 279 & 101.2 & 11.3 & \\
\hline \multirow[t]{2}{*}{ SBP } & No & 509 & 123.6 & 20.8 & \multirow[t]{2}{*}{$<0.001$} \\
\hline & Yes & 280 & 135.4 & 20.2 & \\
\hline \multirow[t]{2}{*}{$\mathrm{DBP}$} & No & 509 & 78.0 & 10.6 & \multirow[t]{2}{*}{$<0.001$} \\
\hline & Yes & 280 & 84.2 & 10.9 & \\
\hline Insulinemia & No & 489 & 8.8 & 4.5 & $<0.001$ \\
\hline$(\mu \mathrm{UI} / \mathrm{ml})$ & Yes & 269 & 13.5 & 7.6 & \\
\hline \multirow[t]{2}{*}{ HOMA - IR } & No & 489 & 2.0 & 1.2 & \multirow[t]{2}{*}{$<0.001$} \\
\hline & Yes & 269 & 3.5 & 2.2 & \\
\hline \multirow[t]{2}{*}{ Glycemia (mg/dl) } & No & 509 & 90.6 & 19.4 & \multirow[t]{2}{*}{$<0.001$} \\
\hline & Yes & 280 & 102.7 & 25.5 & \\
\hline \multirow[t]{2}{*}{ AST (U/L) } & No & 507 & 19.9 & 8.8 & \multirow[t]{2}{*}{$<0.001$} \\
\hline & Yes & 279 & 22.1 & 8.8 & \\
\hline \multirow[t]{2}{*}{$\operatorname{ALT}(\mathrm{U} / \mathrm{L})$} & No & 507 & 18.4 & 9.2 & \multirow[t]{2}{*}{$<0.001$} \\
\hline & Yes & 280 & 25.8 & 15.5 & \\
\hline \multirow{2}{*}{$\begin{array}{l}\text { Total Cholesterol } \\
(\mathrm{mg} / \mathrm{dl})\end{array}$} & No & 509 & 194.5 & 35.7 & \multirow[t]{2}{*}{0.004} \\
\hline & Yes & 280 & 202.5 & 40.2 & \\
\hline \multirow{2}{*}{$\begin{array}{l}\text { HDL Cholesterol } \\
(\mathrm{mg} / \mathrm{dl})\end{array}$} & No & 509 & 59.1 & 15.0 & \multirow[t]{2}{*}{$<0.001$} \\
\hline & Yes & 280 & 50.9 & 14.8 & \\
\hline \multirow{2}{*}{$\begin{array}{l}\text { LDL Cholesterol } \\
(\mathrm{mg} / \mathrm{dl})\end{array}$} & No & 509 & 119.4 & 31.8 & \multirow[t]{2}{*}{0.002} \\
\hline & Yes & 280 & 127.6 & 38.7 & \\
\hline \multirow{2}{*}{$\begin{array}{l}\text { Triglyceridemia } \\
\text { (mg/dl) }\end{array}$} & No & 509 & 91.7 & 41.9 & \multirow[t]{2}{*}{$<0.001$} \\
\hline & Yes & 280 & 146.2 & 106.6 & \\
\hline \multirow[t]{2}{*}{ Alcohol (g/day) } & No & 507 & 20.1 & 30.3 & \multirow[t]{2}{*}{$<0.001$} \\
\hline & Yes & 278 & 35.8 & 38.5 & \\
\hline
\end{tabular}

Legend: BMI: Body Mass Index. SBP: systolic blood pressure. DBP: diastolic blood pressure. HOMA - IR: Insulin resistance index assessed by the Homeostatic Model Assessment. AST: aspartate aminotransferase. ALT: alanine aminotransferase. HDL Cholesterol: High Density Lipoprotein. LDL Cholesterol: Low-density lipoprotein Cholesterol

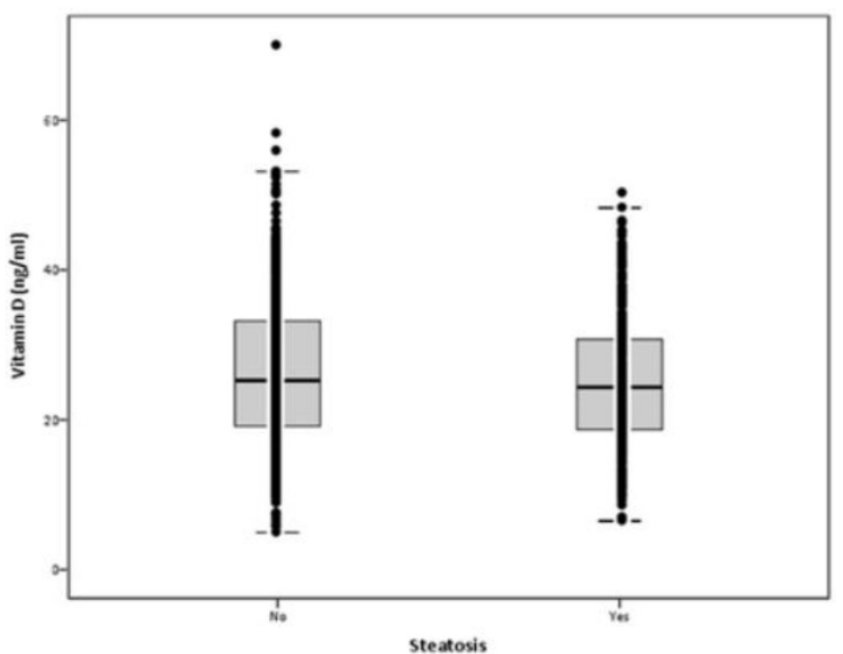

Figure 1. Serum vitamin D levels according to hepatic steatosis $(p=0.071)$ 
There was no direct correlation between BMI and VD serum levels $(\mathrm{r}=-0.193)$, although participants with BMI higher than $30 \mathrm{~kg} / \mathrm{m}^{2}$ had significantly lower VD levels than those with BMI between 25 and $30 \mathrm{~kg} / \mathrm{m}^{2}$ or less than $25 \mathrm{~kg} / \mathrm{m}^{2}(\mathrm{p}<$ 0.001) (Figure 2).

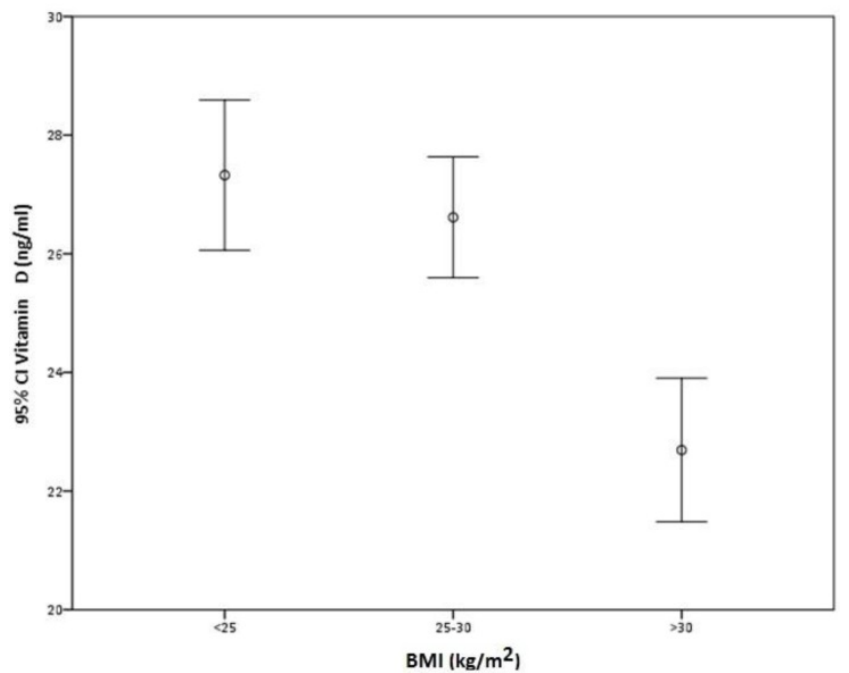

Figure 2. Correlation between BMI and serum vitamin D.

VD serum levels were associated with the presence of MS, only in participants without HS, $(p<0.001)$. In participants with HS, there was no association between VD and the MS $(\mathrm{p}=0.065)$ (Figure 3 and table 3$)$.

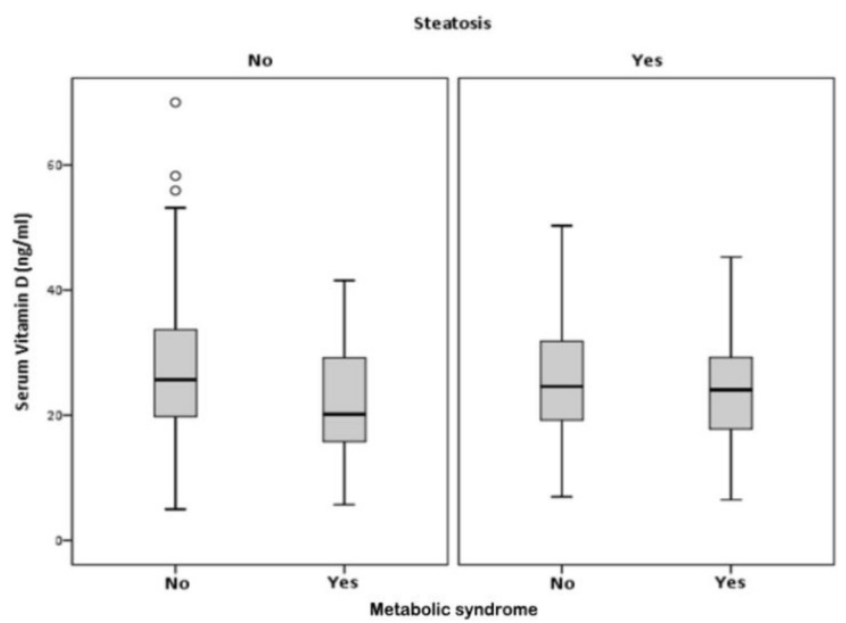

Figure 3. Correlation between, serum vitamin D, hepatic steatosis and metabolic syndrome.

Of the 789 participants, 71 had diabetes $(8.9 \%)$. No significant difference was found in serum VD levels between those with or without diabetes, 23.9 \pm 9.3 vs $26.2 \pm 9.9 \mathrm{ng} / \mathrm{ml} \quad(\mathrm{p}=0.059)$, respectively. Among the 280 participants with HS, prevalence of diabetes was $17.1 \%$, but again no significant difference was found between serum VD levels among those with or without diabetes, $24.1 \pm 9.6 \mathrm{ng} / \mathrm{ml}$ vs $25.4 \pm 8.6 \mathrm{ng} / \mathrm{ml}(\mathrm{p}=0.154)$, respectively.

As shown in table 4, we did not found correlation of different levels of alcohol consumption, with VD deficiency and HS, in our group.

Table 3. Correlation of serum vitamin $D$ with metabolic syndrome (MS) in presence or absence of hepatic steatosis (HS)

\begin{tabular}{llllllll}
\hline HS & MS & $\mathrm{n}$ & & $\begin{array}{l}\text { Mean } \\
(\mathrm{ng} / \mathrm{ml})\end{array}$ & SD & $\begin{array}{l}\text { SE } \\
(\text { mean })\end{array}$ & $p$ \\
\hline No & No & 462 & Serum VD & 26.89 & 10.383 & 0.483 & 0.001 \\
& Yes & 46 & $(\mathrm{ng} / \mathrm{ml})$ & 21.69 & 8.555 & 1.261 & \\
Yes & No & 168 & Serum VD & 25.95 & 9.010 & 0.695 & 0.065 \\
& Yes & 110 & $(\mathrm{ng} / \mathrm{ml})$ & 23.95 & 8.395 & 0.800 & \\
\hline
\end{tabular}

Legend: HS: hepatic steatosis, MS: metabolic syndrome, SD: standard deviation, SE: standard error

Table 4. Correlation of serum vitamin D with hepatic steatosis and alcohol consumption

\begin{tabular}{llllll}
\hline \multirow{2}{*}{ Alcohol consumption } & \multicolumn{2}{l}{ Steatosis } & \multicolumn{4}{l}{ Vitamin D deficiencv } \\
\cline { 5 - 6 } & $\mathrm{n}$ & & $\mathrm{n}$ & $\%$ & $p$ \\
\hline Null & No & 186 & 59 & $31.7 \%$ & 0.340 \\
& Yes & 57 & 22 & $386 \%$ & \\
W: 0-20g/d; M: 0-30g/d & No & 172 & 48 & $27.9 \%$ & 0.463 \\
& Yes & 82 & 27 & $32.9 \%$ & \\
W: $>20 \mathrm{~g} / \mathrm{d} ; \mathrm{M}:>30 \mathrm{~g} / \mathrm{d}$ & No & 149 & 35 & $23.4 \%$ & 0.891 \\
& Yes & 139 & 34 & $24.4 \%$ & \\
& \multicolumn{2}{l}{ Legend: Only 785 participants with serum vitamin D, alcohol consumption and }
\end{tabular}

hepatic steatosis. Vitamin D deficiency: $<20 \mathrm{ng} / \mathrm{mL}$. W: women, M: men.

No correlation was found between VD serum levels, and VD intake, measured by the FFQ, $r=0.075$ $(\mathrm{p}=0.383$ ) (figure 4).

There was no correlation of physical activity with HS ( $p=0.619)$.

The correlation of physical activity with serum VD levels, had no statistical significance, in the all study group $(p=0.316)$, as in the those with serum VD below $20 \mathrm{ng} / \mathrm{ml}$, between 21-29 and above $30 \mathrm{ng} / \mathrm{ml}$ $(p=0.454)$. The separate analysis of serum VD levels, and physical activity, in those with, and without HS, was also with no statistical significance (respectively $\mathrm{p}=0.682$ and $\mathrm{p}=0.193$ ).

Only 57 participants (7.2\%), had serum VD less than $12 \mathrm{ng} / \mathrm{ml}, 18$ of them with HS. We analyzed those participants separately, and the comparison between them and those with serum VD levels above $12 \mathrm{ng} / \mathrm{ml}$, for the presence of HS, did not show any statistically significant difference $(\mathrm{p}=0.587)$.

\section{Discussion}

Liver plays a determinant role in regulation of metabolic homeostasis, glucose and lipid metabolisms, and their abnormalities, ultimately generate hepatic triglyceride accumulation. VD has been referred with a signaling role in hepatic insulin sensitivity and pancreatic islet insulin secretion. 


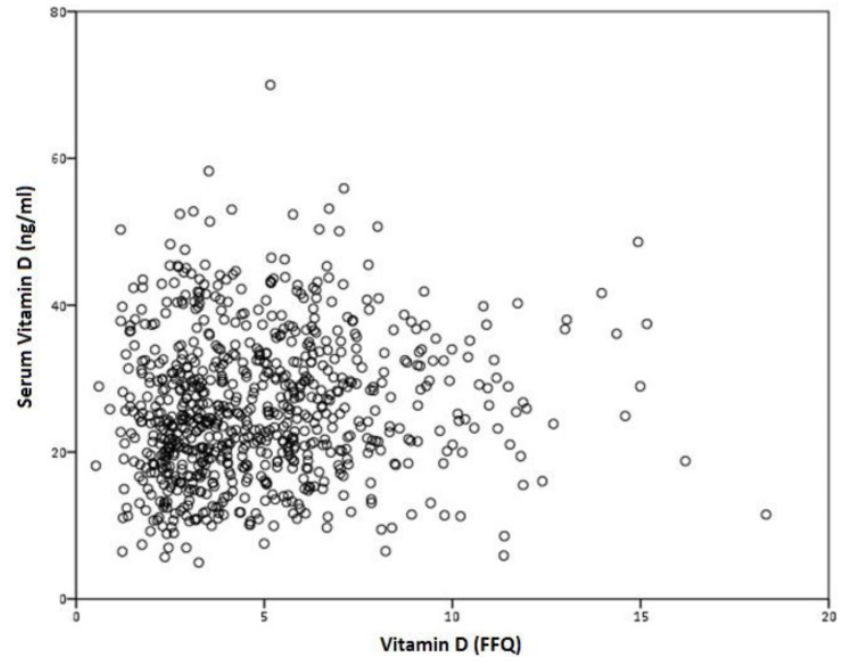

Figure 4. Correlation between serum vitamin $D$ and VD intake, measured by the FFQ, $r=0.075(p=0.383)$.

This information provides a scientific basis for establishing the benefits of the maintenance, or dietary manipulation of adequate vitamin $\mathrm{D}$ status in the prevention and management of obesity-induced T2DM and non-alcoholic fatty liver disease.

The main results of our study suggest that in the Portuguese general population the serum levels of VD are not significantly lower in individuals presenting hepatic steatosis. This finding does not corroborate the findings that low VD serum levels may be a risk factor for steatosis.

The decision of diagnose HS using ultrasound, instead of liver biopsy, considered the gold standard method to diagnose NAFLD, and distinguish it from $\mathrm{NASH}$, is that liver biopsy is unsuitable for large scale studies, due to its invasive nature with possible important side effects, needing hospital admission, at least for a short period, and with elevated costs [43]. In addition, at least in some cases, steatosis is not uniformly distributed, and as the sample represents only about 1:50 000 of the liver, it could provide some misdiagnosis [44]. MRI or CT have great sensitivity, but its cost makes them inappropriate to use in large samples. Even though US has limited sensitivity namely to steatosis under $20 \%$, it is the preferred first-line diagnostic procedure to diagnose HS, since it provides additional diagnostic information and is widely accepted as adequate to large scale studies [1, $41,45,46]$. Even with a low sensitivity of US to diagnose HS, the prevalence of HS in the Portuguese adult population, is in the higher range of the proclaimed rates, for an Occidentalized (or Western) population [1].

HS is related with the features of the MS, excessive weight and obesity, which by them have been associated with hypovitaminosis $\mathrm{D}$, creating the doubt of a possible intermediation of VD as a co-factor for HS.

Despite lower serum VD levels in obese participants, we did not find a direct correlation between higher BMI, and VD serum levels. Our results, do not agree with published data, reporting an association of obesity with VD deficiency, related with VD deposition in body fat, diminishing VD serum bioavailability, namely in obese people [47-49].

VD role in insulin secretion is known [50-52], and impaired glucose tolerance and DM2, were related with lower $25-\mathrm{OH}(\mathrm{D})$, in different populations $[53,54]$, or in winter, when hypovitaminosis D is more prevalent [55]. Despite biological plausibility, available data are also currently insufficient to support recommendation of vitamin D supplementation, in order to a better glucose control, until new scientific evidence $[4,14]$.

Some animal studies, suggested that VD (and possibly other molecules such as nitric oxide) may act as anti-inflammatory mediators, released by skin, after sunlight-derived ultraviolet radiation (UVR), or preventing IR, MS, liver inflammation and progression to NASH [33, 56-58]. In our population, usually exposed to more than 2500 hours of sun/year a year, or even more in southern regions, we did not find statistical correlation of serum VD values with the time of the year of blood samples collection. Also, we did not find significant correlation of serum VD levels and physical exercise, in those with and without HS.

In recent years, interest in VD has increased significantly, as a result of two kinds of published evidence. First, VD was implicated in other conditions apart from the known classical role on calcium homeostasis and bone tissue health, like cardiovascular diseases, IR, cancer, autoimmune diseases and all-cause mortality [59-61]. Second, several epidemiological studies emphasized the evidence that VD deficiency may have pandemic proportions, affecting a very large proportion of the population worldwide [62, 63]. The NHANES III (Third National Health and Nutrition Examination Survey, 1988-2004), reported VD levels below 30 $\mathrm{ng} / \mathrm{ml}$ in $77 \%$ in North Americans [64], and a recent study from different European northern and southern countries, data collected in winter and summer in more than 55000 Europeans (adults and children), reported VD levels less than $12 \mathrm{ng} / \mathrm{ml}$ (considered deficiency) in $13 \%$ of the population, and less than 20 $\mathrm{ng} / \mathrm{ml}$ in $40 \%$ [63].

Although there are differences in study design or population groups, seasonality, and laboratory method that can influence prevalence rates [65], it is peculiar that so large percentage of general 
population would have VD deficits. In fact, it was recently and rightfully questioned the basis for consideration of thresholds for serum VD deficiency levels [66]. Reference values for serum VD were primarily set by bone and calcium needs, and are still a matter of debate if those recommendations can be extended to other conditions or to every population groups possibly influenced by VD deficiency [66]. Misclassifying VD deficiency could lead to under or over diagnoses, a matter of great relevance because supplementation with VD, although rarely in usual therapeutic recommended prescriptions, can lead to toxicity (namely hypercalcemia, hyperphosphatemia, suppressed parathyroid hormone, hypercalciuria and renal stones), and sun exposure can increase risk of skin cancer [67].

The Endocrine Society, in its Practice Guideline [36], defines VD deficiency as total serum 25-(OH)D levels of less than $<20 \mathrm{ng} / \mathrm{mL}$ and VD insufficiency as 21-29 $\mathrm{ng} / \mathrm{mL}$. In the same year, a publication of the Institute of Medicine (IOM) [4], assuming minimal sun exposure, states that total serum 25-(OH)D levels of $16 \mathrm{ng} / \mathrm{mL}$, meet the needs of approximately half of the population, and levels of $20 \mathrm{ng} / \mathrm{mL}$, or greater, meet the needs of nearly all of the population. Deficiency symptoms may appear with levels less than $12 \mathrm{ng} / \mathrm{ml}$, depending upon a range of factors, and some people are potentially at risk for inadequacy with serum 25-(OH)D levels from 12 up to $20 \mathrm{ng} / \mathrm{ml}$. Those recommendations are directed mainly to preservation of bone health. As far as cardiovascular diseases are concerned, type 2 diabetes mellitus or MS, the IOM did not find enough evidence to support VD intake recommendations for prevention, or disease development.

Independently of the considerations of "normality" of VD serum levels it can be argued that lower levels of VD were found to correlate with the presence of NAFLD, MS or diabetes, in individual studies as well as in meta-analysis [26, 27]. The issue we are raising is if that association is causal or just a grouping of risk factors, or in some cases a consequence, such as in advanced liver disease.

The definition of normality thresholds for VD is of great importance for interpretation of our results. In fact, in accordance with the IOM, $28 \%$ of the participants could be at risk of deficiency, and $7.2 \%$ would have deficiency, less than $12 \mathrm{ng} / \mathrm{ml}$ in our population. However, even considering this low cut-off, we still did not find any significant difference in VD serum levels according to the presence of hepatic steatosis $(p=0.587)$.

Other finding of our study, was that there was no significant correlation between serum VD levels and VD intake, measured by the FFQ. That may be related to the effect of sun exposure, able to overcome the effect of nutrient intake, or the data retrieved from the questionnaire. It is well known that food questionnaires have a wide error range, either due to the difficulties of participants recalling their intake or to having a false perception of their food intake, particularly in obese individuals [68-70].

The strength of our study is that we studied a large, unbiased sample of the general population, allegedly healthy, living in a country with an average of 2500 hours of sun/year. The weaknesses are related to the reliability and accuracy usually related to all food questionnaires, as well the use of ultrasound for detection of hepatic steatosis. Also, it is difficult to extrapolate these findings from a normal population, where the presence of steatosis was an incidental finding, to patients that are seeking medical attention because they have hepatic steatosis.

\section{Conclusion}

Our results support that VD deficiency per se does not constitute a risk factor for HS. They need to be confirmed in different populations, but raise the question about the prescription Vitamin D supplementation in this setting, unjustified in the majority of cases or even harmful for some.

\section{Abbreviations}

NAFLD, Nonalcoholic fatty liver disease; NASH, nonalcoholic steatohepatitis; VD, vitamin D; BMI, Body mass index.

\section{Acknowledgements}

The present study received grants from: Portuguese Association for the Study of the Liver (APEF); Gilead Foundation and Gilead Genesis; and Roche supplied laboratorial kits.

APEF, Gilead Foundation and Gilead Genesis and Roche, had no role in the design, analysis or writing of this article, and in the decision to submit the article for publication.

\section{Statement of authorship}

JL: conceived the study, participated in its design, collected the data and wrote the manuscript; SC: participated in collection of data; FV: collection of data; APS: collection of data; IM: collection of data; BO: performed statistical analysis, review the manuscript; ACA: collection of data, review the manuscript; $\mathrm{MB}$ : collection of data, review the manuscript; AC: conceived the study, participated in its design, and review the manuscript; HCP: conceived the study, participated in its design, coordinate the study, and review the manuscript. 
All authors read and approved the final manuscript.

\section{Competing Interests}

A Carvalho, received fees on consultancy, from Intercept and $\mathrm{H}$ Cortez-Pinto received fees on consultancy from Genfit, Intercept and Gilead.

The other authors declare that they have no conflict of interest.

\section{References}

[1] Younossi ZM, Koenig AB, Abdelatif D, Fazel Y, Henry L, Wymer M. Global epidemiology of nonalcoholic fatty liver disease-Meta-analytic assessment of prevalence, incidence, and outcomes. Hepatology. 2016;64(1):73-84.

[2] Williams CD, Stengel J, Asike MI, Torres DM, Shaw J, Contreras M, et al. Prevalence of nonalcoholic fatty liver disease and nonalcoholic steatohepatitis among a largely middle-aged population utilizing ultrasound and liver biopsy: a prospective study. Gastroenterology. 2011;140(1):124-31.

[3] Lonardo A, Bellentani S, Argo CK, Ballestri S, Byrne CD, Caldwell SH, et al. Epidemiological modifiers of non-alcoholic fatty liver disease: Focus on high-risk groups. Digestive and liver disease : official journal of the Italian Society of Gastroenterology and the Italian Association for the Study of the Liver. 2015;47(12):997-1006.

[4] IOM (Institute of Medicine). 2011. Dietary Reference Intakes for Calcium and Vitamin D. Washington, DC: The National Academies Press.

[5] Henry HL. Regulation of vitamin D metabolism. Best practice \& research Clinical endocrinology \& metabolism. 2011;25(4):531-41.

[6] Adams JS, Hewison M. Update in vitamin D. The Journal of clinical endocrinology and metabolism. 2010;95(2):471-8.

[7] DeLuca HF. Overview of general physiologic features and functions of vitamin D. Am J Clin Nutr. 2004;80(6 Suppl):1689s-96s.

[8] Liu PT, Stenger S, Li H, Wenzel L, Tan BH, Krutzik SR, et al. Toll-like receptor triggering of a vitamin D-mediated human antimicrobial response. Science (New York, NY). 2006;311(5768):1770-3.

[9] Smolders J, Menheere P, Thewissen M, Peelen E, Tervaert JW, Hupperts R, et al. Regulatory $\mathrm{T}$ cell function correlates with serum 25 -hydroxyvitamin $\mathrm{D}$, but not with 1,25-dihydroxyvitamin D, parathyroid hormone and calcium levels in patients with relapsing remitting multiple sclerosis. The Journal of steroid biochemistry and molecular biology. 2010;121(1-2):243-6.

[10] von Essen MR, Kongsbak M, Schjerling P, Olgaard K, Odum N, Geisler C. Vitamin $\mathrm{D}$ controls $\mathrm{T}$ cell antigen receptor signaling and activation of human $\mathrm{T}$ cells. Nat Immunol. 2010;11(4):344-9.

[11] De Haes P, Garmyn M, Degreef H, Vantieghem K, Bouillon R, Segaert S. 1,25-Dihydroxyvitamin D3 inhibits ultraviolet B-induced apoptosis, Jun kinase activation, and interleukin-6 production in primary human keratinocytes. Journal of cellular biochemistry. 2003;89(4):663-73.

[12] Lappe JM, Travers-Gustafson D, Davies KM, Recker RR, Heaney RP. Vitamin $\mathrm{D}$ and calcium supplementation reduces cancer risk: results of a randomized trial. Am J Clin Nutr. 2007;85(6):1586-91.

[13] Campbell IT, Jarrett RJ, Rutland P, Stimmler L. The plasma insulin and growth hormone response to oral glucose: diurnal and seasonal observations in the Antarctic. Diabetologia. 1975;11(2):147-50.

[14] Mitri J, Muraru MD, Pittas AG. Vitamin D and type 2 diabetes: a systematic review. European journal of clinical nutrition. 2011;65(9):1005-15.

[15] Zeitz U, Weber K, Soegiarto DW, Wolf E, Balling R, Erben RG. Impaired insulin secretory capacity in mice lacking a functional vitamin D receptor. FASEB journal : official publication of the Federation of American Societies for Experimental Biology. 2003;17(3):509-11.

[16] Maestro B, Davila N, Carranza MC, Calle C. Identification of a Vitamin D response element in the human insulin receptor gene promoter. The Journal of steroid biochemistry and molecular biology. 2003;84(2-3):223-30.

[17] Al-Daghri NM, Al-Attas OS, Alokail MS, Alkharfy KM, Al-Othman A, Draz $\mathrm{HM}$, et al. Hypovitaminosis D associations with adverse metabolic parameters are accentuated in patients with Type 2 diabetes mellitus: a body mass index-independent role of adiponectin? Journal of endocrinological investigation. 2013;36(1):1-6.

[18] Li YC, Kong J, Wei M, Chen ZF, Liu SQ, Cao LP. 1,25-Dihydroxyvitamin D(3) is a negative endocrine regulator of the renin-angiotensin system. The Journal of clinical investigation. 2002;110(2):229-38.

[19] Vaidya A, Williams JS, Forman JP. The independent association between 25-hydroxyvitamin D and adiponectin and its relation with BMI in two large cohorts: the NHS and the HPFS. Obesity. 2012;20(1):186-91.

[20] Engeli S, Schling P, Gorzelniak K, Boschmann M, Janke J, Ailhaud G, et al. The adipose-tissue renin-angiotensin-aldosterone system: role in the metabolic syndrome? The international journal of biochemistry \& cell biology. 2003;35(6):807-25

[21] Cheng Q, Boucher BJ, Leung PS. Modulation of hypovitaminosis D-induced islet dysfunction and insulin resistance through direct suppression of the pancreatic islet renin-angiotensin system in mice. Diabetologia. 2013;56(3):553-62.

[22] Leung PS. The Potential Protective Action of Vitamin D in Hepatic Insulin Resistance and Pancreatic Islet Dysfunction in Type 2 Diabetes Mellitus. Nutrients. 2016;8(3):147.

[23] Chiu KC, Chu A, Go VL, Saad MF. Hypovitaminosis D is associated with insulin resistance and beta cell dysfunction. Am J Clin Nutr. 2004;79(5):820-5.

[24] Kilkkinen A, Knekt P, Aro A, Rissanen H, Marniemi J, Heliovaara M, et al. Vitamin D status and the risk of cardiovascular disease death. American journal of epidemiology. 2009;170(8):1032-9.

[25] Wang TJ, Pencina MJ, Booth SL, Jacques PF, Ingelsson E, Lanier K, et al. Vitamin D deficiency and risk of cardiovascular disease. Circulation. 2008;117(4):503-11.

[26] Eliades M, Spyrou E, Agrawal N, Lazo M, Brancati FL, Potter JJ, et al. Meta-analysis: vitamin D and non-alcoholic fatty liver disease. Alimentary pharmacology \& therapeutics. 2013;38(3):246-54.

[27] Wang X, Li W, Zhang Y, Yang Y, Qin G. Association between vitamin D and non-alcoholic fatty liver disease/non-alcoholic steatohepatitis: results from a meta-analysis. International journal of clinical and experimental medicine. 2015;8(10):17221-34.

[28] Targher G, Bertolini L, Scala L, Cigolini M, Zenari L, Falezza G, et al. Associations between serum 25-hydroxyvitamin D3 concentrations and liver histology in patients with non-alcoholic fatty liver disease. Nutr Metab Cardiovasc Dis. 2007;17(7):517-24

[29] Potter JJ, Liu X, Koteish A, Mezey E. 1,25-dihydroxyvitamin D3 and its nuclear receptor repress human alpha1 (I) collagen expression and type I collagen formation. Liver international : official journal of the International Association for the Study of the Liver. 2013;33(5):677-86.

[30] Bril F, Maximos M, Portillo-Sanchez P, Biernacki D, Lomonaco R, Subbarayan $\mathrm{S}$, et al. Relationship of vitamin D with insulin resistance and disease severity in non-alcoholic steatohepatitis. Journal of hepatology. 2015;62(2):405-11.

[31] Anty R, Hastier A, Canivet CM, Patouraux S, Schneck AS, Ferrari-Panaia P, et al. Severe Vitamin D Deficiency Is Not Associated with Liver Damage in Morbidly Obese Patients. Obesity surgery. 2016;26(9):2138-43.

[32] Patel YA, Henao R, Moylan CA, Guy CD, Piercy DL, Diehl AM, et al. Vitamin D is Not Associated With Severity in NAFLD: Results of a Paired Clinical and Gene Expression Profile Analysis. The American journal of gastroenterology. 2016;111(11):1591-8.

[33] Nakano T, Cheng YF, Lai CY, Hsu LW, Chang YC, Deng JY, et al. Impact of artificial sunlight therapy on the progress of non-alcoholic fatty liver disease in rats. Journal of hepatology. 2011;55(2):415-25.

[34] Kwok RM, Torres DM, Harrison SA. Vitamin D and nonalcoholic fatty liver disease (NAFLD): is it more than just an association? Hepatology. 2013;58(3):1166-74

[35] Craig CL, Marshall AL, Sjostrom M, Bauman AE, Booth ML, Ainsworth BE, et al. International physical activity questionnaire: 12-country reliability and validity. Medicine and science in sports and exercise. 2003;35(8):1381-95.

[36] Holick MF, Binkley NC, Bischoff-Ferrari HA, Gordon CM, Hanley DA, Heaney RP, et al. Evaluation, treatment, and prevention of vitamin D deficiency: an Endocrine Society clinical practice guideline. The Journal of clinical endocrinology and metabolism. 2011;96(7):1911-30.

[37] Matthews DR, Hosker JP, Rudenski AS, Naylor BA, Treacher DF, Turner RC. Homeostasis model assessment: insulin resistance and beta-cell function from fasting plasma glucose and insulin concentrations in man. Diabetologia. 1985;28(7):412-9.

[38] Grundy SM, Cleeman JI, Daniels SR, Donato KA, Eckel RH, Franklin BA, et al. Diagnosis and management of the metabolic syndrome: an American Heart Association/National Heart, Lung, and Blood Institute Scientific Statement. Circulation. 2005;112(17):2735-52.

[39] Lopes C, Aro A, Azevedo A, Ramos E, Barros H. Intake and adipose tissue composition of fatty acids and risk of myocardial infarction in a male Portuguese community sample. Journal of the American Dietetic Association. 2007;107(2):276-86

[40] Ratziu V, Bellentani S, Cortez-Pinto H, Day C, Marchesini G. A position statement on NAFLD/NASH based on the EASL 2009 special conference. Journal of hepatology. 2010;53(2):372-84.

[41] EASL-EASD-EASO Clinical Practice Guidelines for the management of non-alcoholic fatty liver disease. Journal of hepatology. 2016;64(6):1388-402.

[42] Hamaguchi M, Kojima T, Itoh Y, Harano Y, Fujii K, Nakajima T, et al. The severity of ultrasonographic findings in nonalcoholic fatty liver disease reflects the metabolic syndrome and visceral fat accumulation. The American journal of gastroenterology. 2007;102(12):2708-15.

[43] Bravo AA, Sheth SG, Chopra S. Liver biopsy. The New England journal of medicine. 2001;344(7):495-500

[44] Merriman RB, Ferrell LD, Patti MG, Weston SR, Pabst MS, Aouizerat BE, et al. Correlation of paired liver biopsies in morbidly obese patients with suspected nonalcoholic fatty liver disease. Hepatology. 2006;44(4):874-80.

[45] Hernaez R, Lazo M, Bonekamp S, Kamel I, Brancati FL, Guallar E, et al. Diagnostic accuracy and reliability of ultrasonography for the detection of fatty liver: a meta-analysis. Hepatology. 2011;54(3):1082-90.

[46] Byrne CD, Patel J, Scorletti E, Targher G. Tests for diagnosing and monitoring non-alcoholic fatty liver disease in adults. Bmj. 2018;362:k2734.

[47] Holick MF. Vitamin D: importance in the prevention of cancers, type 1 diabetes, heart disease, and osteoporosis. Am J Clin Nutr. 2004;79(3):362-71. 
[48] Wortsman J, Matsuoka LY, Chen TC, Lu Z, Holick MF. Decreased bioavailability of vitamin D in obesity. Am J Clin Nutr. 2000;72(3):690-3.

[49] Holick MF. Vitamin D deficiency. The New England journal of medicine. 2007;357(3):266-81

[50] Norman AW, Frankel JB, Heldt AM, Grodsky GM. Vitamin D deficiency inhibits pancreatic secretion of insulin. Science (New York, NY). 1980;209(4458):823-5.

[51] Clark SA, Stumpf WE, Sar M. Effect of 1,25 dihydroxyvitamin D3 on insulin secretion. Diabetes. 1981;30(5):382-6

[52] Chertow BS, Sivitz WI, Baranetsky NG, Clark SA, Waite A, Deluca HF. Cellular mechanisms of insulin release: the effects of vitamin D deficiency and repletion on rat insulin secretion. Endocrinology. 1983;113(4):1511-8.

[53] Scragg R, Holdaway I, Singh V, Metcalf P, Baker J, Dryson E. Serum 25-hydroxyvitamin D3 levels decreased in impaired glucose tolerance and diabetes mellitus. Diabetes research and clinical practice. 1995;27(3):181-8.

[54] Isaia G, Giorgino R, Adami S. High prevalence of hypovitaminosis D in female type 2 diabetic population. Diabetes care. 2001;24(8):1496.

[55] Campbell IT, Jarrett RJ, Keen H. Diurnal and seasonal variation in oral glucose tolerance: studies in the Antarctic. Diabetologia. 1975;11(2):139-45.

[56] Geldenhuys S, Hart PH, Endersby R, Jacoby P, Feelisch M, Weller RB, et al. Ultraviolet radiation suppresses obesity and symptoms of metabolic syndrome independently of vitamin D in mice fed a high-fat diet. Diabetes. 2014;63(11):3759-69.

[57] Fleury N, Feelisch M, Hart PH, Weller RB, Smoothy J, Matthews VB, et al. Sub-erythemal ultraviolet radiation reduces metabolic dysfunction in already overweight mice. The Journal of endocrinology. 2017;233(1):81-92.

[58] Gorman S, Black LJ, Feelisch M, Hart PH, Weller R. Can skin exposure to sunlight prevent liver inflammation? Nutrients. 2015;7(5):3219-39.

[59] Saliba W, Barnett O, Rennert HS, Rennert G. The risk of all-cause mortality is inversely related to serum $25(\mathrm{OH}) \mathrm{D}$ levels. The Journal of clinical endocrinology and metabolism. 2012;97(8):2792-8.

[60] Chowdhury R, Kunutsor S, Vitezova A, Oliver-Williams C, Chowdhury S, Kiefte-de-Jong JC, et al. Vitamin D and risk of cause specific death: systematic review and meta-analysis of observational cohort and randomised intervention studies. Bmj. 2014;348:g1903.

[61] Ford ES, Zhao G, Tsai J, Li C. Vitamin D and all-cause mortality among adults in USA: findings from the National Health and Nutrition Examination Survey Linked Mortality Study. International journal of epidemiology. 2011;40(4):998-1005

[62] Holick MF. The vitamin D deficiency pandemic and consequences for nonskeletal health: mechanisms of action. Mol Aspects Med. 2008;29(6):361-8.

[63] Cashman KD, Dowling KG, Skrabakova Z, Gonzalez-Gross M, Valtuena J, De Henauw S, et al. Vitamin D deficiency in Europe: pandemic? Am J Clin Nutr. 2016;103(4):1033-44

[64] Ginde AA, Liu MC, Camargo CA, Jr. Demographic differences and trends of vitamin D insufficiency in the US population, 1988-2004. Archives of internal medicine. 2009;169(6):626-32.

[65] LeFevre ML. Screening for vitamin D deficiency in adults: U.S. Preventive Services Task Force recommendation statement. Annals of internal medicine. 2015;162(2):133-40

[66] Manson JE, Brannon PM, Rosen CJ, Taylor CL. Vitamin D Deficiency - Is There Really a Pandemic? The New England journal of medicine. 2016;375(19):1817-20.

[67] World Health Organization, World Cancer Report, Lyon, 2014. International Agency for Research on Cancer (IARC). 2014.

[68] Westerterp KR, Goris AH. Validity of the assessment of dietary intake: problems of misreporting. Current opinion in clinical nutrition and metabolic care. 2002;5(5):489-93.

[69] Trabulsi J, Schoeller DA. Evaluation of dietary assessment instruments against doubly labeled water, a biomarker of habitual energy intake. American journal of physiology Endocrinology and metabolism. 2001;281(5):E891-9.

[70] Heitmann BL, Lissner L. Dietary underreporting by obese individuals--is it specific or non-specific? Bmj. 1995;311(7011):986-9. 